* Especialista em Direito Constitucional pela PUCPR; Mestre em Direito Negocial pela Universidade Estadual de Londrina; Professor Universitário nos cursos de Direito, Administração de Empresas, Ciências Contábeis e Tecnologia em Gestão Comercial da Universidade do Oeste Paulista. E-mail: teofilopp@uol.com.br

** Doutora em Direito das Relações Sociais pela Pontifícia Universidade Católica de São Paulo (PUC/SP). Professora do Programa de Mestrado em Direito Negocial e do Curso de Graduação e Pós Graduação em Direito da Universidade Estadual de Londrina. Coordenadora do Curso de Pós Graduação lato sensu em Direito Civil e Processo Civil da Universidade Estadual de Londrina. E-mail: anaclaudiazuin@sercomtel.com.br

\section{Onerosidade excessiva na alienação fiduciária de coisa móvel}

\section{EXCESSIVE BURDEN ON FIDUCIARY SALE OF MOBILE THING}

Pedro Teófilo de Sá *

Ana Cláudia Corrêia Zuin Mattos do Amaral **

Resumo: O trabalho tem por objetivo analisar o fenômeno da onerosidade excessiva e seu cabimento no contrato de alienação fiduciária em garantia de coisa móvel, diante dos Códigos Civil e de Defesa do Consumidor, considerando se tratar de negócio jurídico sujeito ás autonomias privada e da vontade, diante da relativização da força obrigatória do contrato, sem a perda da boa-fé contratual.

Palavras-chave: Alienação Fiduciária; Onerosidade Excessiva.

Abstract: The study aims to analyze the phenomenon of excessive burden and its place in the contract of chattel mortgage of movable, before the Civil Codes and Consumer Protection, considering it is subject to legal business and private autonomy of the will, before relativization of the binding force of contract, without the loss of good faith contract.

Keywords: Fiduciary sale; Excessive burden. 


\section{INTRODUÇÃO}

O desenvolvimento econômico e social das últimas décadas proporcionou a ampla utilização do contrato de alienação fiduciária em garantia de coisa móvel. O instituto da alienação fiduciária surgiu no Brasil na década de 60 , como forma de fomentar a economia direcionada ao consumo de bens duráveis.

A difusão desse tipo de negócio jurídico fez nascer a necessidade de estudos mais detidos da relação contratual estabelecida. Assim, a nova realidade contratual alcançou tal negócio jurídico direcionada à eticidade, boa-fé e à finalidade social, contempladas pelo Código Civil brasileiro de 2002. Além disso, o Código também fez previsão à onerosidade excessiva como forma de relativização da obrigação de cumprir o avençado. Nesse passo, seguiu e ampliou os preceitos do Código de Defesa do Consumidor em vigor desde 1990 que estabelecia a alteração de cláusula contratual quando houvesse excessiva onerosidade.

A partir de então, os dois veículos normativos disciplinam o assunto da obrigação contratual. É certo que o cumprimento do contrato está conexo à liberdade de contratar e à autonomia privada. Esta, por sua vez, permite a relativização do cumprimento das obrigações assumidas quando houver a onerosidade excessiva.

O contrato de alienação fiduciária em garantia de coisa móvel faz parte da realidade contemporânea alcançada pela autonomia privada e deve caminhar na esteira da boa-fé exercendo sua função social.

Diante dessa nova realidade contratual e considerando a crescente utilização do negócio jurídico denominado alienação fiduciária em garantia, especificamente de coisa móvel, é que se justifica a necessidade do estudo da ocorrência do fenômeno da onerosidade a fim de contribuir para a área do direito em decorrência da difusão e da ampla utilização dessa espécie de negócio jurídico.

Por isso, o objetivo do presente estudo consiste em analisar a ocorrência do fenômeno da onerosidade excessiva no contrato de alienação fiduciária em garantia de coisa móvel, diante dos Códigos Civil e de Defesa do Consumidor. Para tanto, será abordada a alienação fiduciária em garantia desde a antiga Roma, passando por outras disciplinas (direito germânico, inglês) até chegar ao Brasil. Também contemplará as autonomias da vontade, e a privada, na busca da formação da relação jurídica contratual nos Códigos Civil e de Defesa do Consumidor. E, finalmente, será abordada a onerosidade excessiva no contrato 
ONERosidade EXCESSIVA Na ALIENAÇ̃̃o FIDUCIÁRIA DE COISA MÓVEL

de alienação fiduciária em garantia de coisa móvel, partindo, sobretudo, da máxima pactra sunt servanda, passando pela claúsula rebus sic stantibus e teoria da imprevisão.

\section{APONTAMENTOS SOBRE FIDÚCIA E ALIENAÇÃO FIDUCIÁRIA}

O estudo da alienação fiduciária em garantia, pauta-se na fidúcia, apresentando sua origem desde a antiga Roma até chegar ao Brasil, em 1965, através da lei de número $4.728 / 65$, que tratou do mercado de capitais, e suas posteriores alterações.

Desde os romanos já havia a preocupação de assegurar a satisfação do crédito, razão porque instituíram os institutos de tutela ao crédito. Havia uma dualidade, a proteção do credor sem que isso configurasse prejuízo ao devedor (ALVES, 1979, p.1).

A fidúcia aludia à idéia de contrato apoiada na boa-fé, resumindo-se na convenção inter partes onde um recebia a coisa ou direito com o compromisso de restituí-la no final. Nota-se que as ideias de risco e confiança eram inerentes à fidúcia (RESTIFFE, 2000, p.25-6).

A fidúcia era vista como negócio jurídico e tinha como base a confiança estabelecida entre a obrigação assumida e o contrato. Isto porque uma parte recebia o bem com a obrigação de usá-lo para determinado fim, devendo devolvê-lo ao final. A lealdade e a honestidade (boa-fé) eram ressaltadas de maneira implícita (CANUTO, 2004, p.84).

A fidúcia foi originada na antiga Roma, mas apresentou distintas abordagens de acordo com a necessidade das diferentes nações. No período romano, o credor tinha titularidade dominial plena, pautada na confiança e a fidúcia figurava como direito real absoluto se apresentando como: a) fidúcia cum amico que alcançava bens móveis e imóveis, assemelhando-se com o comodato (CANUTO, 2004, p.84-5); b) fidúcia cum creditore (creditore contracta) que considerava a dívida garantida com a transferência da propriedade infungível, pautada na confiança e fundada na boa-fé para evitar lesão; e c) fidúcia remancipationi causa que representava um pacto para emancipação do filho (RESTIFFE, 20000, p.21).

Por outro lado, os poderes do credor fiduciário se limitavam a condição resolutiva na fidúcia germânica que garantia o direito de sequela. Enquanto que, no direito inglês, a fidúcia se caracterizava como: a) trust receipt que era 
usado para bens móveis duráveis, fundado na confiança, e permitia a transferência da propriedade até o resgate da dívida (CANUTO, 2004, p.8894). Suas raízes estavam no negócio fiduciário que acabou influenciando a alienação fiduciária no Brasil; b) mortgage que era usado somente para imóveis e transferia a propriedade definitiva inclusive com a posse ao credor para garantia da dívida até o cumprimento da obrigação, quando deveria ser devolvida ao devedor caracterizando o caráter de resolúvel (RESTIFFE, 2000, p.30-1); e c) chattel mortgage que era advindo do mortgage e de uso exclusivo de bens móveis. Portanto, representa uma hipoteca mobiliária que guarda íntima relação com o penhor do direito germânico (ALVES, 1979, p.29). Nesta, o devedor permanece na posse do bem enquanto estiver adimplente, caso contrário, fica obrigado a entregar o bem ao credor. É exatamente nesse aspecto que aparece a relação com o penhor dos antigos germânicos.

No Brasil, a alienação fiduciária surgiu com a edição da lei de número $4.728 / 65$ que regulou o mercado de capitais prevendo especificamente no artigo 66 sobre a alienação fiduciária de coisa móvel fungível. A finalidade foi difundir a política de crédito e facilitar financiamentos para favorecer o mercado de capitais. Além disso, previu a transferência fiduciária do domínio da coisa, como forma de garantia da solvibilidade. Nesse ponto se assemelhava ao trust receipt do direito inglês.

A edição da mencionada lei resolvera o problema da facilitação do escoamento de produtos, porém surgiu um novo desafio, o da solvibilidade do crédito. Para solucionar tal impasse, foi criado o Decreto-Lei 911/69, que tratou do aspecto processual e alterou a lei de número 4.728/65.

O Decreto-Lei 911/69 possibilitou a busca e apreensão do bem em procedimento sumário autônomo, a ação depósito quando o bem não fosse encontrado com o devedor, e ainda a execução, além da venda do bem. Possibilitou, portanto, a transferência do domínio resolúvel, da posse direta e indireta, assim como a prova escrita por instrumento público ou particular e o registro obrigatório.

Em 1997, a lei de número 4.728/65 foi novamente atualizada através da lei de número 9.514/97, que fez previsão da alienação fiduciária de bem imóvel mediante registro, permitindo a participação de pessoa física ou jurídica, não sendo mais exclusividade das instituições financeiras (CANUTO, 2003, p.10910).

O Código Civil de 2002 tratou da alienação fiduciária de coisa móvel infungível, diferentemente da lei 4.748/65, que tratava de coisa móvel fungível. 
O Código alcançou ainda a propriedade resolúvel e trouxe quatro novidades:

a) não revogou o Decreto-Lei 911/65, que trata do aspecto processual da alienação fiduciária e previu a possibilidade de sub-rogação de terceiro, ou seja, a possibilidade de terceiro pagar a dívida e figurar como credor se subrogando nos seus direitos;

b) criou a propriedade fiduciária de coisa móvel infungível;

c) alterou o artigo $3^{\circ}$ do Decreto-Lei 911/69, prevendo a possibilidade de busca e apreensão com liminar, desde que a mora ou o inadimplemento fossem comprovados;

d) alterou também o artigo 24 da lei de número 9.514/65, que trata das condições de validade do negócio jurídico fiduciário, fazendo inserir o total da dívida, prazo e época do pagamento, além da descrição do bem e identificação dos elementos indispensáveis à sua edificação.

Posteriormente, houve nova alteração da lei de número 4.728/65, com a edição da lei de número 10.931/04 que inseriu o artigo 66-B. Esta alteração regulou o mercado financeiro e de capitais, tratou da garantia de créditos fiscais e previdenciários, além de revogar o artigo 66-A que tratava da coisa móvel fungível e infungível. Possibilitou ainda:

a) a busca e apreensão com liminar quando comprovada a mora ou inadimplemento;

b) prazo de cinco dias para consolidação da posse plena e propriedade ao credor, podendo ser expedido novo certificado de propriedade;

c) retirou a purgação da mora, concedendo ao devedor o prazo de cinco dias para pagar ou restituir o bem;

d) prazo de 15 dias para o devedor responder a ação, a contar da efetivação da liminar, independente de ter sido feito o pagamento.

E, finalmente, a alienação fiduciária sofreu sua última alteração através da edição da lei de número 11.418/07, que atualizou a redação da lei de número 9.514/97, permitindo às pessoas físicas e jurídicas fazerem a contratação e, não apenas as instituições do sistema financeiro. Dessa forma, permitiu ainda a democratização do negócio jurídico fiduciário por meio de nova redação do artigo 22 .

\subsection{Negócio fiduciário}

Após a exposição da trajetória da alienação fiduciária nas distintas nações ao longo do tempo, necessário se faz registrar que o negócio fiduciário é 
caracterizado pela transmissão de uma coisa ou direito a outra pessoa, para ser devolvida em momento futuro, após o bem ter atingido a sua finalidade. A partir de então foi necessário diferenciar a alienação fiduciária do negócio fiduciário germânico, neste, "...o transferente confia na lealdade e honestidade da outra parte em se servir da propriedade ou direito solenemente transferido." (RESTIFFE, 2000, p.32). Na alienação, a propriedade resolúvel é transferida para garantia do cumprimento da obrigação, ao passo que no negócio germânico, o credor ficava com a propriedade plena.

É possível concluir que o negócio jurídico é expressão da autonomia privada e necessita da confiança das partes na formação do vínculo, além da boa-fé para a formação do contrato. Para estabelecer o liame entre os três termos (negócio fiduciário, alienação fiduciária e autonomia privada), é necessário alinhavar, rapidamente que, a alienação fiduciária representa o negócio jurídico em que o devedor fiduciante transfere a propriedade resolúvel ao credor fiduciário com a finalidade de garantia real (desde que registrado) da solvibilidade de obrigação contraída. Assim, o proprietário (devedor fiduciante) tem temporariamente a sua propriedade suspensa até que se cumpra a obrigação.

A alienação fiduciária, além de ser negócio jurídico, é ainda contrato bilateral, oneroso, formal, comutativo, acessório, sinalagmático, consensual, de adesão e complexo, que serve de título para constituição da propriedade fiduciária (DEDA, 2000, p.12-6). É importante ressaltar que a alienação não se confunde com o negócio jurídico fiduciário romano, germânico, nem tampouco com o trust receipt. No entanto, apresenta pontos convergentes com o chattel mortgage.

As diferenças entre o trust receipt e a alienação fiduciária se baseiam em:

a) trust receipt: 1) permite a venda de mercadoria diretamente em nome do financiador; 2) o banco pode reaver o bem dado em garantia que está na posse direta do devedor; 3) a propriedade não é resolúvel; 4) a propriedade do bem é transferida do vendedor para o financiador (credor) e não para o comprador (devedor);

b) alienação fiduciária em garantia: 1) a venda deve ser realizada pelo credor, haja vista que o devedor não pode fazê-la mesmo quando vencida a dívida, sob pena de cometer estelionato; 2) o credor não pode recuperar o bem, pois este serve apenas de garanta, ademais a sua finalidade não foi a venda, mas o empréstimo garantido; 3) a propriedade é resolutiva. 
A propriedade fiduciária é direito real sobre coisa própria do credor, isto é, objeto da garantia real, necessitando da propriedade resolúvel para que se caracterize.

Com todas as alterações legais, a alienação fiduciária passou a alcançar bens móveis e imóveis e vem tratada desde a lei de número 4.728/65 (alterada pela lei de número 9.514/97, e, posteriormente, alterada pelas leis de números 10.931/04 e 11.481/07) e pelo Decreto-Lei 911/69. Enquanto o Código Civil de 2002 trouxe nos artigos 1.361 a 1.368-A, as linhas gerais a serem aplicadas à alienação fiduciária, subsidiariamente.

As duas regras previram a garantia fiduciária de bens móveis com a transmissão do domínio resolúvel e da posse direta e indireta, independente da tradição efetiva (ocorrendo então a tradição ficta). O devedor passa a possuidor direto e depositário, não cabendo mais a prisão civil, por força das súmulas 31 do Supremo Tribunal Federal e 419 do Supremo Tribunal de Justiça.

A alienação fiduciária de bem imóvel foi regulada pela lei de número 9.514/97 e alterada pela lei de número 11.481/07, que concedeu nova redação e tratou da propriedade resolúvel. Essa atualização estabeleceu dentre outras providências que o credor deverá pedir a intimação do devedor para que efetue o pagamento das parcelas vencidas e vincendas no prazo de 15 dias após o recebimento da notificação (FIGUEIRA JUNIOR, 2005, p.19-20). No entanto, parece existir contra-senso, haja vista que na ocorrência de inadimplemento e mora, além de o devedor não conseguir saldar as vencidas, pode ser que não consiga pagar as vincendas. Desta forma, a alteração do parágrafo $7^{\circ}$ do artigo 26 da lei de número 9.514/97 acentua ainda mais o desequilíbrio contratual.

\section{FORMAÇÃO DA RELAÇÃO JURÍDICA CONTRATUAL NOS CÓDIGOS CIVIL E DE DEFESA DO CONSUMIDOR}

Para se chegar à ocorrência fenomênica da onerosidade excessiva é preciso lembrar que o negócio jurídico passa pela formação da relação jurídica contratual nos dois sistemas o civil e o consumerista.

Na visão contemporânea do direito civil, existe o estudo da formação da relação jurídico-contratual como condutora da formação do negócio jurídico (enquanto espécie do gênero ato jurídico). $O$ vínculo existente é resultado da vontade e da confiança expressadas pelo ato jurídico e previsto na moldura apresentada pelo Código Civil para a harmonização dos interesses que devem ser pautados na boa-fé e na confiança que paulatinamente vem sendo resgatadas (FACHIN, 2003, p.91-3). 
É, portanto, observado que o objeto da relação jurídica está pautado na vontade e na confiança que afeta o comportamento das partes (BETTI, 1969, p.26). Desta forma, exige dessas partes a boa-fé e a preocupação com a função social em busca do equilíbrio contratual. Para isso, é exigido o respeito das autonomias da vontade e privada (esta última, por sua vez, representa a forma de regular e nortear a autonomia da vontade).

O elemento volitivo se destaca como elemento de fundo para a formação do negócio jurídico. Pois é a partir da vontade como forma de expressão do ato jurídico (seja latu ou strictu sensu), pautada na confiança, que se alcança o negócio jurídico. Em especial, o negócio jurídico da alienação fiduciária de coisa móvel.

A partir dessa visão mister se faz explicitar a diferenciação entre as duas espécies de ato jurídico. De um lado o latu sensu, que resulta ou não do querer; e do outro, o strictu sensu, importante no querer que desfecha no lícito e ilícito, e conhecido pela doutrina tradicional como ato jurídico strictu sensu, ao passo que a moderna o denomina negócio jurídico (GOMES, 2010, p.201-7).

A conexão entre ato e negócio jurídico necessita de distinção. O primeiro contém a manifestação volitiva, ao passo que o segundo busca o efeito pretendido com o querer expressado pelo ato. Portanto, é possível afirmar que o fundamento e os efeitos do negócio jurídico se apóiam na vontade norteada pela autonomia privada, devido ao fato de representar o elemento volitivo pautado na confiança que conduz ao negócio jurídico (AZEVEDO, 2002, p.5).

O negócio jurídico se forma da relação contratual pautado na vontade, sendo representada pela autonomia da vontade. Por sua vez, a autonomia da vontade é auxiliada pelo elemento confiança que está apoiado na autonomia privada em busca do equilíbrio das relações contratuais.

É possível, portanto, tecer a alusão de que o negócio jurídico representa o veículo que permite a realização do seu próprio núcleo central, isto é, a autonomia privada, materializada no contrato. É ainda o resultado do ato jurídico strictu sensu como manifestação da vontade e pautado pela autonomia privada. Tem como conseqüência a criação, modificação ou extinção das relações jurídicas molduradas pelo direito civil através dos princípios da socialidade, eticidade e operabilidade. Deste modo, possibilita que o negócio jurídico da alienação fiduciária se sujeite a aplicação da regra do artigo 478 do Código Civil que trata da onerosidade excessiva.

A materialização da obrigação assumida pelas partes é firmada pelo contrato como forma de expressar e assegurar a proteção e o equilíbrio da 
relação vinculativa das partes fundada na confiança inserta nos sistemas civil e comsumerista. Isso ocorre como observância e respeito às cláusulas gerais e aos conceitos legais indeterminados para sedimentar a autonomia privada.

Desde o Código de Hammurabi que a obrigação resultante do vínculo deveria ser cumprida (HESPANHA, 1996, p.36). Salvo quando houvesse exceção imprevisível. Isto porque ao firmarem o vínculo, uma parte faz despertar na outra a confiança e a crença de que o cumprimento ocorrerá.

Contemporaneamente, pode ser observado nas molduras civilística e consumerista, a onerosidade excessiva como forma de oposição ao cumprimento da obrigação assumida (FACHIN, 2010, p.68-9). Ocorre, então, a adequação do fato social ao sistema jurídico da modernidade.

A obrigatoriedade do cumprimento do contratado era pautada no pacta sunt servanda como resultado do forte conteúdo de credibilidade firmado na doutrina clássica das obrigações que considerava presente no contrato a boafé das partes. Era também justificada a exigência do cumprimento da obrigação como verdadeira lei entre as partes.

A preocupação com os imprevistos que impedissem o cumprimento da obrigação assumida fez surgir a cláusula rebus sic stantibus. Essa origem ocorreu como forma de tutela do interesse das partes e para salvaguardar o futuro cumprimento da obrigação materializada no contrato. Portanto, as partes ao contratarem não poderiam causar prejuízos a cada outra, pois existiam as preocupações de não causar lesão (defendida desde os romanos), e de as partes deverem respeitar o contrato até mesmo durante o seu cumprimento.

Todo contrato estava pautado na boa-fé, e os contratantes deveriam respeitar reciprocamente a liberdade contratual como forma de expressar a liberdade de contratar representada pelo princípio da autonomia da liberdade contratual. Tal liberdade serve de equilíbrio entre a liberdade das manifestações da vontade das partes que está pautada na liberdade de escolha. Também está pautada no livre arbítrio e na obediência a autonomia da vontade como forma de expressão da autodeterminação imposta pela lei.

Na modernidade, o equilíbrio contratual também é dependente da boafé. Além disso, tem a confiança como elemento central do negócio jurídico. A presença da confiança conjuntamente com a boa-fé contratual é representada pela eficácia das cláusulas gerais e dos conceitos legais indeterminados. Por sua vez, esses fatores atenderão ao solidarismo contratual em busca do equilíbrio na relação contratual conforme apontam os artigos 421 e 422 do Código Civil. 
Desta forma, a confiança e a boa-fé representam os novos paradigmas da realidade contratual contemporânea por se caracterizarem como princípios e diretrizes das relações contratuais. Ambas combatem a abusividade e a onerosidade excessiva na relação contratual e contribuem para a eficácia e efetividade dos fins sociais do contrato. A confiança exerce papel redutor da complexidade pressupondo obediência ao dirigismo contratual caracterizado pelas autonomias da vontade e privada.

O descumprimento das obrigações materializadas no contrato gera crise na confiança e no direito. Na perspectiva da inibição dessa crise, os Códigos Civil e de Defesa do Consumidor trouxeram as cláusulas gerais e os conceitos legais indeterminados. Tanto as cláusulas como os conceitos contribuem para a efetivação dos princípios gerais do direito e da supressão de lacuna para assegurar o equilíbrio e a equidade contratual.

A eficácia do negócio jurídico não deve sofrer interferência da crise da confiança das partes marcada pelo descumprimento contratual (MARQUES, 2007, p.20-38). Para tanto, a atuação do dirigismo contratual ocorrerá por meio da autonomia privada como forma de limitação da autonomia da vontade. A autonomia privada estabelece o limite para o exercício da autonomia da vontade e afeta a liberdade de contratação, além de servir como forma de supressão de lacuna. Tal premissa retoma a ideia romana de não causar a lesão, complementada atualmente com a finalidade de assegurar a dignidade humana.

Portanto, a autonomia privada é princípio geral de direito e considera o querer do sujeito e a manifestação da vontade. Enquanto que a autonomia da vontade é princípio de direito privado e está relacionada ao poder do sujeito criar as regras contratuais e a elas se submeter (NERY JUNIOR, 2008, p.500).

Novamente, é possível afirmar que o negócio jurídico é meio de concretizar a autonomia privada conduzida pelo dirigismo que está manifestado nos artigos 421 e 422 do Código Civil. Tal autonomia é um fenômeno abstrato que pode ser observado a partir de três prismas fundamentados no:

a) poder de criar, modificar ou extinguir relações jurídicas;

b) princípio aberto informador do sistema que justifica o funcionamento do próprio sistema jurídico e;

c) método de interpretação, haja vista que indica o norte para o alcance do sentido da norma jurídica.

Por sua vez, a autonomia da vontade é expressão do poder de autodeterminação das partes e está pautada na autonomia privada que se apresenta como moldura legal à limitação da liberdade de contratar. 
As cláusulas gerais estão insertas na moldura legal da autonomia privada que são formulações genéricas (dispositivos não direcionados) que podem ser aplicadas em várias situações, justamente devido à vagueza da expressão (TOMASZEWISKI, 2006, p.3, 33-7). Portanto, sua aplicação necessita da intervenção hermenêutica.

Essas cláusulas gerais orientam o interprete permitindo ao juiz dúplice função, isto é, a de vinculá-lo a aplicação e a liberdade de estabelecer o alcance. Tais cláusulas estão presentes nos artigos $187,421,422,623,868$, parágrafo único do artigo 927, 1.028, 1.634, III e parágrafo único do artigo 2.035 do Código Civil.

Os conceitos legais indeterminados também estão insertos na moldura legal da autonomia privada e são termos abstratos, vagos e imprecisos trazidos na lei. Eles servem para fornecer ao julgador a possibilidade de valoração do caso concreto pautado pela legalidade, a exemplo do que se observa da análise do art. $4^{\circ}$ da Lei de Introdução as Normas de Direito Brasileiro. Esse permite ao julgador, em caso de omissão legal, decidir de acordo com a analogia e os princípios gerais de direito, suprimindo lacuna. Tais conceitos estão dispostos nos artigos 122, 188, II, 251, 581, 927, 1.643, I e 2.019 do Código Civil.

Os princípios gerais de direito não estão positivados no sistema. Portanto, são regras em branco que permitem a supressão de lacuna, fazendo tornar concreto o direito. É nesse momento que o juiz se valerá das cláusulas gerais e dos conceitos legais indeterminados para efetivar a concreção do direito.

O Código Civil de 2002 inovou ao prever a boa-fé como princípio fundamental da cláusula geral dos contratos, a exemplo do artigo 422. A partir da previsão legal, a boa-fé é standard da conduta para a interpretação contratual e o preenchimento de lacuna. Isso ocorre para se evitar abusos, manter a confiança ou minimizar possível crise, com o foco central da segurança das relações jurídicas.

A boa-fé tem três funções: a) servir para interpretar e estabelecer o limite do alcance da norma; b) integrar a norma quando supre lacuna; e c) limitar a vontade das partes à moldura da autonomia privada (AMARAL, 2006, p.421). Nesse contexto, se apresenta como sub-moldura.

A boa-fé se divide em objetiva e subjetiva e está prevista nos artigos 113, 187 e 422 e parágrafo único do artigo 2.035 do Código Civil. A subjetiva é investigativa, enquanto que a objetiva constitui cláusula geral e está relacionada às responsabilidades pré e até, pós-contratual (REALE, 2003, p.77-8). 
A função social do contrato é outra cláusula geral integrante da moldura da autonomia privada, sendo norma de ordem pública. Portanto, alcança os aspectos econômicos e sociais. Por isso, o juiz, valendo-se da vagueza do termo, preenche o conceito e supre lacuna, para dar maior efetividade a pessoa humana.

Como decorrência lógica é preciso uma rápida abordagem sobre a formação da relação jurídica no Código de Defesa do Consumidor a partir da identificação das partes envolvidas, passando pelo conceito de consumidor através das teorias maximalista e minimalista. $\mathrm{O}$ conceito de consumidor na teoria minimalista alcança apenas as figuras tradicionais previstas no Código de Defesa do Consumidor. Enquanto que na maximalista, o consumidor seria qualquer pessoa que adquirisse o produto e o utilizasse mesmo como meio de produção e comercialização (MARQUES, 2006, p.303-5).

A exposição das duas correntes doutrinárias suscita convivência e diálogo dos sistemas civil e consumerista com relação à aplicação dos princípios e não da conceituação de consumidor. Isso ocorre porque a finalidade tanto do diálogo como da convivência é o equilíbrio da relação contratual.

As teorias contratuais civilista e consumerista se pautam na cláusula geral da boa-fé e na confiança. Todas estão diametralmente guiadas pela autonomia privada para evitar abusividade e, também, lesão. Eis o momento em que convivem e dialogam dentro do sistema permitindo a intercomunicação sistêmica.

A razão dessa convivência está apoiada no equilíbrio contratual e na vulnerabilidade do consumidor. Por excelência, o consumidor é sujeito de direitos fundamentais, trazidos pelos artigos $5^{\circ}$, XXXII e 170, V da Constituição Federal. Ambos os artigos marcam o direito do consumidor como direito humano de nova geração (pós-modernidade) relacionado à garantia do princípio da dignidade humana. Percebe-se, claramente a busca do equilíbrio e confiança na relação contratual.

A questão não é simples e permeia o campo da hermenêutica e da aplicabilidade da norma. Por isso, depende da ponderação de valores constitucionais, mas que não foram esgotados por não constituir o objeto do trabalho. Diante do caso concreto, na ausência de caracterização da relação de consumo (de acordo com a teoria finalista), o Código Civil deve ser aplicado. O fundamento da aplicabilidade está na busca pela preservação do contrato, da vontade e na valorização da confiança, limitados pela autonomia privada.

A formação do vínculo contratual nas esferas civil e do consumidor deve privilegiar o equilíbrio, inclusive na fase da execução da obrigação quando pode 
surgir o fenômeno da onerosidade excessiva. Isso justificaria a desobrigação do cumprimento do pactuado.

\section{ONEROSIDADE EXCESSIVA NO CONTRATO DE ALIENAÇÃO FIDUCIÁRIA EM GARANTIA DE COISA MÓVEL}

Os romanos se preocupavam com o cumprimento do que fora pactuado a partir da máxima pacta sunt servanda. No entanto, a máxima sofreu relativização por meio da cláusula rebus sic stantibus e pela teoria da imprevisão e, finalmente, pela onerosidade excessiva prevista nos Códigos Civil de 2002 e de Defesa do Consumidor.

Seguindo os preceitos romanos influenciados pelo direito canônico, o negócio jurídico depois de concluído se sujeitava à máxima pacta sunt servanda (GONÇALVES, 2006, p.168-9). Isso ocorria como forma de expressão da equidade e da boa-fé, cuja ideia fora propagada pelo cristianismo. Por isso, as partes tinham que cumprir o pactuado, uma vez assumido o compromisso da manutenção do equilíbrio.

A cláusula rebus sic stantibus surgiu como forma de relativização da máxima pacta sunt servanda. Essa cláusula trazia a presunção implícita de que o cumprimento da obrigação não poderia alterar a situação fática (apenas para contratos comutativos, de trato sucessivo e execução diferida).

Para tentar explicar e fundamentar a revisão contratual após o surgimento da cláusula rebus sic stantibus, apareceram inúmeras teorias. Dentre elas, as principais são a teoria da pressuposição de Windscheid, a de base subjetiva do negócio de Paul Oertmann e a de base subjetiva de Karl Larens (BARROS, 2007, p.317).

A teoria da pressuposição tem como foco a orientação e autolimitação da vontade declarada que não estava condicionada a qualquer situação. Pela teoria de base subjetiva do negócio, o foco era a manifestação mental emitida no momento da concretização do negócio. Por fim, para a teoria subjetiva de Karl Larens, considerada a teoria objetiva de Kaufmann interessa fatores que alteram o resultado do negócio mesmo não tendo sido previstos e, por sua vez, trata da possibilidade da onerosidade excessiva.

Desta forma, a teoria da imprevisão tinha como objetivo abrandar a aplicação do princípio pacta sunt servanda para proteger uma das partes 
quando houvesse mudança brusca à época da contratação. Por isso, a observação de que visava evitar lesão e promover equidade.

A cláusula rebus sic stantibus passou por um período de descrédito no século XVIII, mas fora resgatado no início do século XX, com o declínio da escola da exegese (SOUZA, 2005, p.358-60). Tais fatos favoreceram ao reaparecimento da cláusula com o termo de teoria da imprevisão renovando o pensamento medieval e permitindo o entendimento de que o estado de fato poderia afetar a execução da obrigação, diferentemente do que se observava no medievo.

Foi após o ressurgimento da teoria da imprevisão que se originou a onerosidade excessiva como condição da teoria. Isso ocorreu fundado na posição justinianeia, cuja preocupação se direciona à formação do contrato e de seu equilíbrio (AZEVEDO, 2004, p.34-40).

\section{CONCLUSÃO}

A onerosidade excessiva deve ser aplicada separada da teoria da imprevisão, e não como seu requisito.

A justificativa para a utilização da onerosidade excessiva de maneira autônoma à teoria da imprevisão, é que, para esta, além de fundar-se no equilíbrio contratual, considera-se a existência de enriquecimento e prejuízo inesperado e imprevisível para uma das partes. Enquanto que, para a onerosidade se dispensam todos os requisitos. Basta apenas que durante a execução aconteça um fato que influencie no cumprimento da obrigação, tornando insuportável o cumprimento. Portanto, qualquer das partes poderá pleitear a mudança do modo de execução.

Desta forma, o teor do artigo 480 do Código Civil deveria prever a possibilidade das partes mudarem o modo de execução, e não apenas assegurar tal direito a uma delas. Assim, estaria preservando o equilíbrio contratual em respeito à autonomia privada, fundado nas cláusulas gerais e nos conceitos legais indeterminados, cujo escopo precípuo é evitar lesão.

Portanto, quando o artigo 480 traz a onerosidade excessiva, esta dever ser entendida como fenômeno jurídico que gera desequilíbrio obrigacional contratual por conta da insuportabilidade da execução do contrato que pode afetar as duas partes contratantes. Cabe notar ainda que a redação do artigo 478 do Código Civil traz os requisitos da teoria da imprevisão, quais sejam: vantagem extrema, acontecimento extraordinário e imprevisível. 
O artigo em comento trata da ocorrência da onerosidade excessiva, pois faz referência ao cumprimento da prestação assumida e não a formação da relação contratual. Assim, todos os requisitos colacionados perdem efeito. Obviamente, não cabe a aplicação dos requisitos da teoria da imprevisão que tratam de acontecimentos anteriores à execução do contrato.

Os requisitos excessiva onerosidade, vantagem extrema e o acontecimento extraordinário colacionados no artigo 478 são de difícil caracterização. Além disso, dependem do caso concreto e apresentam grau de subjetividade (AZEVEDO, 2004, p.40).

A análise do teor do artigo 479 do Código Civil deixa claro ser possível evitar a resolução do contrato se a outra parte, o réu, se oferecer a modificar equitativamente a condição objeto da discussão no caso concreto. Sem, contudo, prever adequação por força da sentença. Assim, a seção IV do capítulo II do Código Civil, que trata da resolução por onerosidade excessiva, deveria receber a denominação de onerosidade excessiva.

A título de lege ferenda, os artigos em comento deveriam receber nova redação:

a) Artigo 478. Caracteriza-se a onerosidade excessiva quando para qualquer das partes houver fato que provoque o desequilíbrio no cumprimento das prestações, capaz de gerar a impossibilidade do seu cumprimento;

b) Artigo 479. A resolução poderá ser evitada, oferecendo-se o réu, a modificar equitativamente as condições do contrato ou por decisão judicial;

c) Artigo 480. Nos contratos de execução continuada ou diferida se a prestação se tornar insuportável para qualquer das partes de modo a afetar o equilíbrio contratual, poderão pleitear a redução ou a alteração do modo de execução para evitar a onerosidade excessiva.

A nova redação do artigo 478 caracteriza objetivamente a ocorrência do fenômeno jurídico da onerosidade excessiva. Enquanto que o artigo 480 restabelece o equilíbrio contratual pautado na autonomia privada, adequandose o contrato à nova realidade e evitando lesão, além de ressaltar a confiança.

Desta forma, poder-se-á contribuir para a redução da crise da confiança que é base do negócio jurídico, inclusive o fiduciário, além de valorizar a socialização, a finalidade do contrato, a circulação de riquezas e a manutenção da sua função social.

Ao reconhecer a onerosidade excessiva como fenômeno que somente pode ocorrer durante a execução das prestações, o Código Civil trilha a mesma esteira do Código de Defesa do Consumidor, isto é, evitar a desproporcionalidade 
da prestação para que não ocorra lesão, pautado na moldura constitucional do princípio da dignidade humana.

O fato novo deve ocorrer durante a execução da prestação. Portanto, não pode pretender mudar a vontade declarada no momento em que o negócio foi efetivamente concretizado, como, por exemplo, a vontade de contratar declarada. Seria necessário que durante a execução aparecesse um fenômeno novo que justificasse a mutabilidade das condições da prestação ou modo de cumprimento, sem alterar a vontade declarada de contratar ou de mantê-la efetivada.

O reconhecimento do fenômeno da onerosidade excessiva busca o equilíbrio contratual e evita lesão. Estas preocupações veem sendo consideradas desde os romanos e encontram amparo nas regras justinianas (AZEVEDO, 2004, p.38-41). Modernamente, recebe a proteção dos Códigos Civil e de Defesa do Consumidor quando preveem a possibilidade de adequação do contrato e seu cumprimento, fundado na boa-fé e respeitado a função social.

É importante verificar o equilíbrio desde as tratativas até a materialização do contrato. Caso não ocorra, aplica-se a teoria da imprevisão, porém se o fato é novo e surgiu durante a execução, aplica-se a onerosidade excessiva para preservar a relação entre a prestação e a contraprestação.

Portanto, pelo instituto da onerosidade excessiva se mantém a vontade das partes e o equilíbrio tanto dos originários da época da contratação como durante a execução. Isso ocorre para preservar o equilíbrio das partes, da prestação e contraprestação como destaque da confiança que os vinculou.

A ocorrência de fenômenos capazes de impossibilitar o cumprimento da obrigação para quaisquer das partes, deverá ser analisada à luz da possibilidade da aplicação da onerosidade excessiva com a finalidade de assegurar o equilíbrio ente a prestação e a contraprestação. Para tanto, cabe a aplicação do artigo 480 combinada com o artigo 317 do Código Civil que trata do equilíbrio entre o valor da prestação devida e o montante de sua execução. Isto porque existem duas situações diferentes, a da prestação devida e o que é exigido.

Certamente que, para a aplicação da onerosidade excessiva trazida pelo artigo 480 tanto do que consta no atual Código Civil quanto daquele a título de lege ferenda, o poder hermenêutico do interprete permeará as cláusulas gerais e os conceitos legais indeterminados, identificando a função social, a boa-fé objetiva, para poder aplicá-lo.

É claramente observado o dirigismo contratual que proporciona a efetividade da autonomia privada na busca do equilíbrio contratual das relações 
obrigacionais existentes para evitar lesão. Nesse momento, dialogam complementarmente o Código Civil e o de Defesa do Consumidor. Ambos estão vinculados pela verticalidade dos princípios constitucionais, em específico o da dignidade da pessoa humana, que também é fundamento da república. Desta forma, a confiança acaba sendo sedimentada, uma vez que é elemento fundante do vínculo estabelecido no negócio jurídico, em especial da alienação fiduciária em garantia de coisa móvel.

A questão do Código de Defesa do Consumidor ser resultante de direito fundamental, dialogando com o sistema civil, necessita de estudos mais aprofundados, ficando, portanto, para outro momento.

Modernamente, a imutabilidade das relações jurídicas não deve refletir a garantia da segurança jurídica como outrora. Pelo contrário, para que haja segurança jurídica o seu fundamento deve ser a equidade contratual que caminha numa nova esteira, a da boa-fé objetiva, fundada na função social do contrato e sob o comando emergente e supremo do princípio da dignidade humana.

A preocupação não se restringe apenas à seara civil. O Código de Defesa do Consumidor, no seu artigo $6^{\circ}, \mathrm{V}$ traz a previsão da onerosidade excessiva que se caracteriza com a ocorrência de fatos supervenientes a contratação pautado no princípio da equivalência contratual. Novamente, fica caracterizada a autonomia da onerosidade excessiva com relação à teoria da imprevisão.

A Constituição Federal deve coordenar a intercormunicação sistêmica, ou ainda, o diálogo das fontes. Isso ocorre para auxiliar na aplicação finalista do conceito de consumidor que permite ao Código de Defesa do Consumidor assegurar o equilíbrio contratual pautado na manutenção da confiança (sustentados pelo princípio da dignidade humana), entre fiduciante e fiduciário.

A ocorrência da onerosidade excessiva no contrato de alienação fiduciária em garantia de coisa móvel afeta diretamente a segurança da relação contratual pautada na confiança. Essa confiança deve ser preservada por conta da manutenção do equilíbrio contratual, a fim de evitar lesão, com espeque na garantia da dignidade dos contratantes.

Ao visar a máxima efetividade do resultado normativo dos dois códigos, ambos devem estar em constante diálogo de complementariedade para garantir a finalidade e o equilíbrio contratual (MARQUES, 2005, 2007). Com isso, proporcionam a eficácia e efetividade do respeito às cláusulas gerais e conceitos legais indeterminados, destacando a boa-fé objetiva pautada na função social do contrato. Isso reforça a confiança esperada pelas partes desde o momento das tratativas iniciais até a execução do contrato. 
O resultado desse diálogo hermenêutico levará ao resgate da confiança que é responsável pelo vínculo do negócio jurídico. Por sua vez, o vínculo deve ser entabulado e respeitado como forma de fomento do negócio jurídico refletindo no meio social cuja finalidade central é fornecer a máxima efetividade do princípio da dignidade humana.

\section{REFERÊNCIAS}

ALVES, José Carlos Moreira. Da Alienação Fiduciária em Garantia. 2.ed., Rio de Janeiro: Forense, 1979.

AMARAL, Francisco. Direito Civil Introdução. 6. ed. rev. atual. de acordo com o novo Código Civil. Rio de Janeiro: Renovar, 2006.

AZEVEDO, Álvaro Villaça. Teoria Geral dos Contratos Típicos e Atípicos. 2. ed. São Paulo: Atlas, 2004.

AZEVEDO, Antônio Junqueira de. Negócio Jurídico: Existência,Validade e Eficácia. 4. ed. Atualizada de acordo com o Código Civil. São Paulo:Saraiva, 2002.

BARROS, André Borges de Carvalho. HIRONAKA, Giselda M. F. Novaes. TARTUCE, Flávio (coord). Direito Contratual. Temas Atuais. Princípio da Conservação dos Contratos. São Paulo: Método, 2007.

BETTI, Emilio. Teoria geral do negócio jurídico. t.1. Coimbra: Coimbra, 1969.

CANUTO, Elza Maria Alves. Alienação Fiduciária de Bem Móvel. Belo Horizonte; Del Rey, 2004.

DEDA. Artur Oscar de Oliveira. Alienação Fiduciária em Garantia. São Paulo: RT, 2000.

FACHIN, Luiz Edson. Teoria crítica do Direito Civil à luz do novo Código Civil Brasieiro. 2. ed. revista e atualizada. Rio de janeiro: Renovar, 2003. 
FIGUEIRA JUNIOR, Joel Dias. Ação de Busca e Apreensão em Propriedade Fiduciária. São Paulo: RT, 2005.

GOMES, Orlando. Introdução ao Direito Civil. 20. ed. Revista e atualizada por Edvaldo Brito e Reginalda Paranhos de Brito. Rio de Janeiro: Forense, 2010.

GONÇALVES, Carlos Roberto. Direito Civil Brasileiro. v.1. parte geral, $3^{\text {a }}$. ed. Revista e atualizada. São Paulo: Saraiva, 2006.

Direito Civil Brasileiro. v.3. Contratos e atos Unilaterais. São Paulo: Saraiva, 2006.

HESPANHA, Benedito. Teoria da Imprevisão no Direito Brasileiro e no Mercosul. Revista Justiça do Direito, v.9, n.9. Passo Fundo, 1996.

MARQUES, Cláudia Lima. Contratos no Código de Defesa do Consumidor. 5. Ed. São Paulo: RT.2005.

MARQUES, Cláudia Lima(coord). DUQUE, Marcelo Schenk.

NORDEMIER, Carl Friedrich (et al). A Nova Crise do Contrato: Estudos sobre a Nova Teoria Contratual. São Paulo: RT, 2007.

BENJAMIM, Antonio Herman. MIRAGEM, Bruno. Comentários ao Código de Defesa do Consumidor. 2a . ed. São Paulo: RT, 2006.

Contratos no Código de Defesa do Consumidor - o novo regime das relações contratuais. $5^{\text {a }}$. ed. rev. atual. ampl. São Paulo: RT, 2006.

NERY JUNIOR, Nelson. ANDRADE, Rosa Maria de. O Novo Código Civil e legislação extravagante anotados. São Paulo: RT, 2008.

REALE, Miguel. Estudos Preliminares do Código Civil. São Paulo: Saraiva, 2003.

RESTIFFE NETO, Paulo. RESTIFFE, Paulo Sérgio. Garantia Fiduciária. 3. ed. revista, atualizada e ampliada. São Paulo: RT, 2000. 
TOMASZEWISKI, Adauto (autor e coord). BENFANTTI, Fábio Fernandes Neves. NORTE, Janaína Braga. et al. Lições Fundamentais de Direito: Negócio jurídico. V.2. Londrina: Midiograf - Gráfica e Editora, 2006.

Recebido em: 2012-03-30 Aprovado para publicação em: 2012-12-11

Como citar: DE SÁ, Pedro Teófilo; DO AMARAL, Ana Cláudia CorrêiaZuin Mattos.Onerosidade excessiva na alienação fiduciária de coisa móvel. Scientia Iuris, Londrina, v.16, n.2, p.9-28, dez. 2012. DOI: 10.5433/2178-8189.2012v16n2p9. 